\title{
Nutrient Removal Efficiencies of Chlorella vulgaris from Urban Wastewater for Reduced Eutrophication
}

\author{
Ravipratap Singh, Rohan Birru, G. Sibi \\ Department of Biotechnology, Centre for Research and Post Graduate Studies, Indian Academy Degree College (Autonomous), \\ Bengaluru, India \\ Email: gsibii@gmail.com
}

How to cite this paper: Singh, R., Birru, R. and Sibi, G. (2017) Nutrient Removal Efficiencies of Chlorella vulgaris from Urban Wastewater for Reduced Eutrophication. Journal of Environmental Protection, 8, 111.

http://dx.doi.org/10.4236/jep.2017.81001

Received: December 2, 2016

Accepted: January 2, 2017

Published: January 5, 2017

Copyright $\odot 2017$ by authors and Scientific Research Publishing Inc. This work is licensed under the Creative Commons Attribution International License (CC BY 4.0).

http://creativecommons.org/licenses/by/4.0/

(c) (i) Open Access

\begin{abstract}
Urban wastewater contains both organic and inorganic nutrients and discharge of untreated water increases nitrogen and phosphorous content in water bodies leading to eutrophication problem. Physical and chemical treatment of urban waste water produces large quantities of waste sludge associated with secondary pollution. Microalgae can assimilate nutrients especially nitrogen and phosphorous from wastewater for their growth and produce valuable biomass and lipid. This study was performed to determine the growth of Chlorella vulgaris in urban wastewater (UWW) and Bold's basal medium (BBM) thereby identifying cost effective growth medium for microalga cultivation. In addition, nutrient removal abilities of $C$. vulgaris from various dilutions of urban waste water were explored at 10 days cultivation period. Specific growth rate, biomass and lipid content were higher in microalgae grown in urban waste water than BBM. The highest lipid productivity of $14.31 \mathrm{mg}$. $\mathrm{L}^{-1} \cdot$ day $^{-1}$ was achieved in the culture grown in UWW medium which exceeded the BBM at 1.15 fold. The amount of nutrient removal tended to increase with higher dilutions of UWW. Removal rates of upto $87.9 \%$ and $98.4 \%$ were recorded for total nitrogen and total phosphorous by $C$. vulgaris. The results emphasized that urban waste water as a cost effective growth medium for higher biomass and lipid production accompanied with the nutrient removal efficiency of microalgae to reduce eutrophication.
\end{abstract}

\section{Keywords}

Chlorella vulgaris, Wastewater, Nutrient Removal, Biomass, Lipid, Eutrophication 


\section{Introduction}

Increasing industrialization and population explosion result in contamination of wastewater with available water resources. Discharge of urban waste water into water bodies introduces high levels of nitrogen and phosphorous which leads to eutrophication. Nutrient removal is an important aspect of wastewater treatment as eutrophication causes oxygen depletion in aquatic environments, increase in undesired vegetation, loss of aquatic flora and fauna. Phosphorous removal from waste water includes chemical treatment followed by physical treatment; however this method produces large quantities of waste sludge. Algae induced chemical processes are used to eliminate nitrogen and phosphorous [1] [2]. Microalgae require nitrogen and phosphorous as major nutrients besides other micronutrients and produce valuable biomass. Various synthetic media are used for growing microalgae but are associated with costs which exceed the value of final products under large scale cultivation [3]. For economic viability of algal biomass and lipid production, inputs to algal cultivation must be inexpensive. Waste water from urban areas is a cheap source of nutrients and could be used as growth medium for sustainable microalgal cultivation thereby reducing the need of resources like freshwater and fertilizers [4] [5]. Microalgae have adaptability and ability to utilize inorganic nutrients from wastewater. Cultivation of microalgae in wastewater reduces greater levels of fresh water usage and reduces the nitrogen inputs [6]. In addition to biomass and lipid productivities, microalgae are reported to have potential environmental benefits through removing nutrients from waste water [7] [8] [9] [10]. Integrating nutrient removal from wastewater with microalgae cultivation is one effective method to reduce the cost of large scale biofuel production [11] [12] and it would not cause secondary pollution [13].

Microalagae are used to treat various wastewaters in recent times [14] [15] [16] [17] [18]. Algae can assimilate nitrogen and phosphorous from wastewater for their growth at less operational costs [19] and also play an important role in elimination of contaminants from waste water. Utilization of wastewater for microalgal cultivation minimizes the nutrients supply and fresh water usage along with removal of organic and inorganic pollutants. In this study, comparative analysis of growth medium on the growth of microalgae was done using urban waste water and Bold's basal medium. Parallel analysis of nutrient removal capacity by the microalgae isolated from wastewater was also investigated.

\section{Experimental Methods}

\subsection{Inoculum Collection, Identification and Scale-Up}

Urban waste water (UWW) was collected from Bangalore and was characterized in terms of $\mathrm{pH}$, electrical conductivity, temperature, biological oxygen demand, chemical oxygen demand, total organic carbon, total nitrogen and total phosphorous using APHA method [20]. The waste water was poured into a closed $250 \mathrm{ml}$ bottles and exposed in sunlight for 3 weeks. The upper layer of the water was inoculated in agar plates enriched with BG11 medium containing ampicillin 
$\left(200 \mu \mathrm{g} \cdot \mathrm{ml}^{-1}\right)$ to control the bacterial growth. Agar plating technique was used to isolate the microalgae and the plates were incubated at $25^{\circ} \mathrm{C} \pm 2{ }^{\circ} \mathrm{C}$ under cool white fluorescent light ( $40 \mu \mathrm{mol}$ photons $\mathrm{m}^{-2} \cdot \mathrm{s}^{-1} ; 15 \mathrm{~h}$ light $/ 9 \mathrm{~h}$ dark) until algal growth was detected. The isolates were purified by streak plating and individual colonies were diluted in distilled water. Species of single cells were obtained using capillary pipette under microscope followed by inoculation into fresh media. After appropriate growth, cells were observed to confirm the single culture and the capillary method was repeated until pure culture was obtained. Identification of the algal isolates was carried out by following standard protocols [21] [22] and the database http://web.biosci.utexas.edu/utex/default.

Species of Chlorella, Scenedesmus, Pandorina and Oscillatoria were the major isolates identified and cultivated using urban waste water as scale up medium for a period of 6 days at $24^{\circ} \mathrm{C} \pm 2^{\circ} \mathrm{C}$ under illumination $(12 \mathrm{~h}$ light $/ 12 \mathrm{~h}$ dark). Chlorella vulgaris was selected and used for further studies as this strain could achieve relatively high biomass concentration among other isolates when cultivated in urban wastewater.

\subsection{Influence of Growth Medium on Microalgae}

Both Urban Waste Water (UWW) and Bold's Basal Medium (BBM) were used to determine the influence of growth medium on microalgal growth. Various parameters such as specific growth rate, biomass concentration, pigment concentration, total proteins and carbohydrates content and lipid productivity were determined. All experiments were performed in triplicates and the average values were statistically analyzed.

\subsection{Specific Growth Rate and Biomass Productivity}

Specific growth rate $\left(\mu \cdot \mathrm{d}^{-1}\right)$ of the microalgae was calculated according to the following formula [23].

$$
\mu=\frac{\ln \left(N_{t} / N_{0}\right)}{T_{t}-T_{0}}
$$

where, $N_{t}$ and $N_{0}$ are the dry cell weight concentration $\left(\mathrm{g} \cdot \mathrm{L}^{-1}\right)$ at the end $\left(T_{t}\right)$ and start $\left(T_{0}\right)$ of log phase respectively.

Biomass $\left(\mathrm{g} \cdot \mathrm{L}^{-1}\right)$ of $C$. vulgaris grown in waste waster medium and BBM was determined by measuring the optical density of samples at $600 \mathrm{~nm}\left(\mathrm{OD}_{600}\right)$ using UV-Vis spectrophotometer. Biomass concentration was then calculated by multiplying $\mathrm{OD}_{600}$ values with 0.6 , a predetermined conversion factor obtained by plotting $\mathrm{OD}_{600}$ versus dry cell weight (DCW). DCW was determined gravimetrically by centrifuging the algal cells $(3000 \times \mathrm{g}, 10 \mathrm{~min})$ and drying.

$$
\text { Biomass concentration }=\mathrm{OD}_{680} \times 0.6
$$

The biomass productivity $\left(\mathrm{g} \cdot \mathrm{L}^{-1} \cdot \mathrm{d}^{-1}\right)$ was calculated according to Equation (2),

$$
\text { Biomass productivity }=\left(B_{t}-B_{0}\right) / d
$$

where $B_{t}$ was the final biomass concentration, $B_{0}$ is the initial biomass concentration and $d$ is the cultivation time. 


\subsection{Pigment Assay}

Cellular pigments were determined using a spectrophotometric method after extraction with $80 \%$ acetone [24] [25]. Briefly, microalgal pellet was resuspended in phosphate buffer $(0.1 \mathrm{M}, \mathrm{pH}$ ) and sonicated for 10 mins. This was followed by addition of $80 \%$ acetone, vortexing and incubation in the dark for 15 mins. The suspension was centrifuged and the supernatant was measured in a spectrophotometer.

Subsequently, the amount of pigments was calculated using the following formulae

$$
\begin{gathered}
C_{a}=12.21 A_{663}-2.81 A_{646} \\
C_{b}=20.13 A_{646}-5.03 A_{663} \\
C_{t}=1000 A_{470}-3.27 C_{a}-104 C_{b} / 198
\end{gathered}
$$

where $C_{a}$ is the chlorophyll a, $C_{b}$ is the chlorophyll b, and $C_{t}$ is the total carotenoids $\left(\mu \mathrm{g} \cdot \mathrm{mL}^{-1}\right)$.

\subsection{Protein Assay}

The extraction of proteins from microalgae was performed using alkali method. Aliquots of algal sample were centrifuged and $0.5 \mathrm{~N} \mathrm{NaOH}$ was added to the pellet followed by extraction at $80^{\circ} \mathrm{C}$ for 10 mins. The mixture was centrifuged and protein content of the supernatant was estimated using Bovine Serum Albumin (BSA) as standard [26].

\subsection{Carbohydrate Assay}

Cellular carbohydrates were estimated using the anthrone method [27] after hot alkaline extraction [28]. Briefly, microalgal pellets were resuspended in distilled water and then heated in $40 \%(\mathrm{w} / \mathrm{v}) \mathrm{KOH}$ at $90^{\circ} \mathrm{C}$ for $1 \mathrm{~h}$. After cooling down, ice cold ethanol was added and stored at $-20^{\circ} \mathrm{C}$ overnight followed by centrifugation. The pellet was resuspended in distilled water and then reacted with anthrone reagent. D-glucose was used as standard and the colour development was read at $578 \mathrm{~nm}$ in a spectrophotometer.

\subsection{Total Lipid Estimation}

Lipid extraction from dried algal cells were carried out by chloroform:methanol extraction method [29]. Dried algal cells added with distilled water were ultrasonicated and mixed with chloroform: methanol (2:1). The mixture was left for 30 mins in a water bath $\left(30^{\circ} \mathrm{C}\right)$ and filtered through a Whatman No.1 filter paper. The filtrate was transferred to another screw cap tube containing $\mathrm{NaCl}$ solution (0.9\%) and the purified chloroform layer was evaporated to a constant weight in a fuming hood under vacuum at $60^{\circ} \mathrm{C}$. The total lipid content of dry weight was calculated using the following Equation (3).

$$
\text { Lipid content }(\%)=\left(m_{2}-m_{0}\right) / m_{1} \times 100 \%
$$

where $m_{1}$ is the weight of the dried algal cells, $m_{0}$ is the weight of the empty new screw cap tube and $m_{2}$ is the weight of the new screw cap tube with the dried li- 
pids.

Lipid productivity $\left(\mathrm{g} \cdot \mathrm{L}^{-1} \cdot \mathrm{d}^{-1}\right)$ was determined using the following Equation (4).

$$
\text { Lipid productivity }=\text { Biomass productivity } \times \text { Lipid content }
$$

\subsection{Nutrient Removal Efficiency}

Urban waste water was diluted with three initial dilutions (10\%, 20\% and 30\%) using distilled water to determine the nutrient removal efficiency of Chlorella in batch experiments for a period of 10 days. The contents of total phosphorous (P) and total nitrogen $(\mathrm{N})$ before and after the cultivation period were determined [20] by centrifuging a $10 \mathrm{ml}$ liquid culture sample at $8000 \mathrm{rpm}$ for $10 \mathrm{~min}$.

\section{Results and Discussion}

The urban wastewater was characterized for its physicochemical properties and the $\mathrm{pH}$, electrical conductivity and temperature were $6.6 \pm 0.13,2.314\left(\mathrm{mS} \cdot \mathrm{cm}^{-1}\right)$ and $30^{\circ} \mathrm{C}$. The COD, BOD and TOC of the wastewater were $697 \pm 14.15 \mathrm{mg} \cdot \mathrm{L}^{-1}$, $974 \pm 22.04 \mathrm{mg} \cdot \mathrm{L}^{-1}$ and $257 \pm 27.98 \mathrm{mg} \cdot \mathrm{L}^{-1}$. The total nitrogen and phosphorous were $192.27 \pm 0.16 \mathrm{mg} \cdot \mathrm{L}^{-1}$ and $39.97 \pm 6.7 \mathrm{mg} \cdot \mathrm{L}^{-1}$.

Microalgae isolated from natural environments could adapt better and produce good results [30]. It is reasonable to hypothesize that species that naturally develop in wastewater should perform better than most others in commercial scale cultivation on wastewaters. Hence urban waste water was chosen as growth medium in this study. The results showed that among the algal strains isolated from wastewater environment, Chlorella ranked among the top ones in terms of maximal growth rate and biomass productivity. The results from Table 1 indicate that the growth and biochemical composition of the $C$. vulgaris varied with the type of the medium used. After 10 days of cultivation, Urban Waste Water (UWW) medium obtained the maximum biomass concentration of $1.13 \mathrm{~g} \cdot \mathrm{L}^{-1}$ and biomass productivity of $0.19 \mathrm{~g} \cdot \mathrm{L}^{-1}$, which was higher than that of Bold's

Table 1. Effect of growth medium on biomass production, chlorophyll biosynthesis and lipid accumulation of Chlorella vulgaris.

\begin{tabular}{ccc}
\hline Parameters & Bold's basal medium & Urban waste water \\
\hline Specific growth rate $\left(\mu \mathrm{d}^{-1}\right)$ & $1.12 \pm 0.03$ & $1.06 \pm 0.02$ \\
Total chlorophyll $\left(\mathrm{mg} \cdot \mathrm{L}^{-1}\right)$ & $11.36 \pm 0.92$ & $9.37 \pm 0.54$ \\
Total carotenoids $\left(\mathrm{mg} \cdot \mathrm{L}^{-1}\right)$ & $4.7 \pm 0.10$ & $4.8 \pm 0.97$ \\
Total protein $\left(\mathrm{mg} \cdot \mathrm{L}^{-1}\right)$ & $58.7 \pm 0.56$ & $63.7 \pm 1.76$ \\
Total carbohydrates $\left(\mathrm{mg} \cdot \mathrm{L}^{-1}\right)$ & $196 \pm 1.64$ & $187 \pm 3.61$ \\
Biomass $\left(\mathrm{g} \cdot \mathrm{L}^{-1}\right)$ & $1.09 \pm 0.04$ & $1.13 \pm 0.02$ \\
Biomass productivity $\left(\mathrm{g} \cdot \mathrm{L}^{-1} \cdot \mathrm{d}^{-1}\right)$ & $0.17 \pm 0.03$ & $0.19 \pm 0.01$ \\
Lipid content $(\% \mathrm{DW})$ & $7.52 \pm 0.31$ & $8.31 \pm 0.35$ \\
Lipid productivity $\left(\mathrm{mg} \cdot \mathrm{L}^{-1} \cdot \mathrm{d}^{-1}\right)$ & $12.38 \pm 1.01$ & $14.31 \pm 0.38$ \\
\hline
\end{tabular}


Basal Medium (1.09 $\mathrm{g} \cdot \mathrm{L}^{-1}$ and $\left.0.17 \mathrm{~g} \cdot \mathrm{L}^{-1}\right)$. This scenario was different with specific growth rate i.e. $1.12 \mu \cdot$ day $^{-1}$ was observed in BBM where as it was 1.06 $\mu \cdot$ day $^{-1}$ in UWW. C. vulgaris has produced a biomass of $2.7 \mathrm{~g} \cdot \mathrm{L}^{-1}$ in urban waste water [14] and in this study $1.13 \mathrm{~g} \cdot \mathrm{L}^{-1}$ was obtained. Higher biomass was obtained in wastewater medium than BG11 medium [31] and similar results were produced in the present work. The chlorophyll biosynthesis increased in the Bold's Basal Medium (BBM). The maximum chlorophyll content $\left(11.36 \mathrm{mg} \cdot \mathrm{L}^{-1}\right)$ was obtained in BBM whereas it was $9.37 \mathrm{mg} \cdot \mathrm{L}^{-1}$ in UWW medium. Total carotenoids and protein were higher in cells grown in UWW medium and recorded 4.7 and $58.7 \mathrm{mg} \cdot \mathrm{L}^{-1}$ respectively. However, total carbohydrates were increased in BBM $\left(196 \mathrm{mg} \cdot \mathrm{L}^{-1}\right)$. The biomass productivity by $C$. vulgaris in the urban wastewater is $0.19 \mathrm{~g} \cdot \mathrm{L}^{-1} \cdot \mathrm{d}^{-1}$ and similar values were reported earlier [32] using municipal wastewater. The other species of Chlorella grown under municipal wastewater resulted in biomass productivity of $0.055-0.60 \mathrm{~g} \cdot \mathrm{L}^{-1} \cdot \mathrm{d}^{-1}$ [30] [33] [34] [35].

For lipid contents, no statistically significant differences between the UWW and BBM were observed. However, the volumetric lipid productivities of the cultures grown in UWW were enhanced notably due to their high cell density. The highest lipid productivity of $14.31 \mathrm{mg} \cdot \mathrm{L}^{-1} \cdot \mathrm{day}^{-1}$ was achieved in the culture grown in UWW medium which exceeded the BBM at 1.15 fold. In a study using artificial wastewater medium by Feng et al., [36], 42\% lipid content and 147 $\mathrm{mg} \cdot \mathrm{L}^{-1} \cdot \mathrm{d}^{-1}$ of lipid productivity were obtained from $C$. vulgaris whereas $8.31 \%$ and $14.31 \mathrm{mg} \cdot \mathrm{L}^{-1} \cdot \mathrm{d}^{-1}$ were produced in this study using urban waste water as growth medium.

Urban waste water contains both organic and inorganic phosphate which can be readily assimilated by algae. Phosphorus $(\mathrm{P})$ is an important macronutrient for microlalgal growth and microalgae assimilate phosphorus as inorganic orthophosphate for production of phospholipids, ATP and nucleic acids [37]. Phosphorous uptake by microalgae is affected by algal physiology as well as $\mathrm{P}$ concentrations and its chemical forms. Waste water contains nitrogenous matter in the form of ammonium ions, ammonia and organic nitrogen along with other oxidized form of nitrogen. The presence of various forms of nitrogen and phosphorous in wastewater leads to eutrophication [38]. C. vulgaris has a high potential to reduce nutrients in secondary waste water treatment plants effluents [39] [40] [41] while simultaneously producing algal biomass with sufficient lipids content and an acceptable fatty acids profile for use as a biodiesel feedstock [42]. Nutrient uptake is realized via the active transport of ions across the cell membrane. The efficiency of nutrient removal by microalgae is related to its ability to reduce the nitrogen and phosphorous levels in the wastewater. Nutrient removal efficiency depends on the concentrations of nitrogen and phosphorous present in water [43]. Urban wastewater often contained high concentrations of nitrogen and phosphorus, and dilution with fresh water is needed before use to increase the transmission of light in while cultivation. Urban waste water was diluted as the initial concentrations of nitrogen and phosphorous of the waste water was higher than the recommended concentration of microalgae hence various 
Table 2. Nutrient removal performance of Chlorella vulgaris in different UWW concentrations at 10 days cultivation period.

\begin{tabular}{ccccc}
\hline & \multicolumn{2}{c}{ Initial concentration $(\mathrm{mg} / \mathrm{l})$} & \multicolumn{2}{c}{ Final concentration $(\mathrm{mg} / \mathbf{l})$} \\
\cline { 2 - 5 } & Total N & Total P & Total N & Total P \\
\hline $10 \%$ & $21.37 \pm 0.25$ & $1.84 \pm 0.22$ & $3.61 \pm 1.31$ & $0.12 \pm 0.04$ \\
$20 \%$ & $37.46 \pm 1.62$ & $4.12 \pm 0.14$ & $7.25 \pm 0.47$ & $0.09 \pm 0.06$ \\
$30 \%$ & $59.31 \pm 2.74$ & $9.61 \pm 1.23$ & $7.14 \pm 2.54$ & $0.15 \pm 0.03$ \\
\hline
\end{tabular}

dilutions of wastewater was prepared using distilled water. Both nitrogen and phosphorous removal amounts in different initial concentrations of UWW for 10 days cultivation are represented in Table 2.

The total nitrogen removal efficiencies recorded were $83.1 \% \pm 0.14 \%, 78.3 \% \pm$ $0.06 \%, 87.9 \% \pm 0.11 \%$ in $10 \%, 20 \%$ and $30 \%$ dilutions. Up to $84.11 \%$ nitrogen uptake from urban waste water was reported by Chlorella [44] and an $87.9 \%$ nitrogen removal was found in this study. The amount of removed total phosphorous tended to increase with higher initial dilutions of UWW. Approximately, 93.4, 97.8 and $98.4 \%$ were removed from the growth medium containing $10 \%, 20 \%$ and $30 \%$ of UWW respectively. Hongyang et al., [45] reported the removal of nitrogen $(77.8 \%)$ and phosphorous (88.8\%) from soybean processing wastewater using Chlorella pyrenoidosa. $C$. vulgaris grown in tertiary municipal wastewater with initial concentration of 8.7 and $1.71 \mathrm{mg} \cdot \mathrm{L}^{-1}$ of total nitrogen and phosphorous has completely removed the nutrients at the end of 4 days cultivation [46]. In other studies, removal rate of total nitrogen was observed between $61.1 \%-91.8 \%$ by Chlorella sp. grown in municipal wastewater [47] [48] [49] whereas $87.9 \%$ removal was recorded in this study. It was observed that $98.4 \%$ of total phosphorous was removed which is higher than removal rate reported in previous studies [46] [50] [51].

\section{Conclusion}

The results clearly emphasized that urban waste water is a cost effective growth medium for higher biomass and lipid production in microalgae. The nutrient removal efficiency by $C$. vulgaris isolated from wastewater proved that microalgae are potential in removing nitrogen and phosphorous from highly concentrated nutrient rich urban wastewater. This study highlights the more effective alternative ecofriendly approach for wastewater treatment using microalgae to eliminate eutrophication.

\section{References}

[1] Kesaano, M. and Sims, R.C. (2014) Algal Biofilm Based Technology for Wastewater Treatment. Algal Research, 5, 231-240. https://doi.org/10.1016/j.algal.2014.02.003

[2] Sanudo-Wilhelmy, S.A., Tovar-Sanchez, A., Fu, F.X., Capone, D.G., Carpenter, E.J. and Hutchins, D.A. (2004) The Impact of Surface Adsorbed Phosphorous on Phytoplankton Redfield Stoichiometry. Nature, 432, 897-901. https://doi.org/10.1038/nature03125 
[3] Li, X., Xu, H. and Wu, Q. (2007) Large Scale Biodiesel Production from Microalga Chlorella Protothecoides through Heterotrophic Cultivation in Bioreactors. Biotechnology and Bioengineering, 98, 764-771. https://doi.org/10.1002/bit.21489

[4] Pittman, J.K., Dean, A.P. and Osundeko, O. (2011) The Potential of Sustainable Algal Biofuel Production Using Wastewater Resources. Bioresource Technology, 102, 17-25. https://doi.org/10.1016/j.biortech.2010.06.035

[5] Driver, T., Bajhaiya, A. and Pittman, J.K. (2014) Potential of Bioenergy Production from Microalgae. Current Sustainable/Renewable Energy Reports, 1, 94-103. https://doi.org/10.1007/s40518-014-0011-8

[6] Rawat, I., Bhola, V., Ranjith Kumar, R. and Bux, F. (2013) Improving the Feasibility of Producing Biofuels from Microalgae Using Wastewater. Environmental Technology, 34, 1765-1775. https://doi.org/10.1080/09593330.2013.826287

[7] Park, J.B., Craggs, R.J. and Shilton, A.N. (2011) Wastewater Treatment High Rate Algal Ponds for Biofuel Production. Bioresource Technology, 102, 35-42. https://doi.org/10.1016/j.biortech.2010.06.158

[8] Boelee, N.C., Temmink, H., Janssen, M., Buisman, C.J.N. and Wijffels, R.H. (2011) Nitrogen and Phosphorus Removal from Municipal Wastewater Effluent Using Microalgal Biofilms. Water Research, 45, 5925-5933.

https://doi.org/10.1016/j.watres.2011.08.044

[9] Shi, J., Podola, B. and Melkonian, M. (2007) Removal of Nitrogen and Phosphorus from Wastewater Using Microalgae Immobilized on Twin Layers: An Experimental Study. Journal of Applied Phycology, 19, 417-423.

https://doi.org/10.1007/s10811-006-9148-1

[10] Levine, R.B., Costanza-Robinson, M.S. and Spatafora, G.A. (2011) Neochloris Oleoabundans Grown on Anaerobically Digested Dairy Manure for Concomitant $\mathrm{Nu}$ trient Removal and Biodiesel Feedstock Production. Biomass Bioenergy, 35, 40-49. https://doi.org/10.1016/j.biombioe.2010.08.035

[11] Wang, C., Yu, X., Lv, H. and Yang, J. (2013) Nitrogen and Phosphorus Removal from Municipal Wastewater by the Green Alga Chlorella sp. Journal of Environmental Biology, 34, 421-425.

[12] Chen, R., Li, R., Deitz, L., Liu, Y., Stevenson, R.J. and Liao, W. (2012) Freshwater Algal Cultivation with Animal Waste for Nutrient Removal and Biomass Production. Biomass Bioenergy, 39, 128-138. https://doi.org/10.1016/j.biombioe.2011.12.045

[13] Zamani, N., Noshadi, M., Amin, S., Niazi, A. and Ghasemi, Y. (2011) Effect of Alginate Structure and Microalgae Immobilization Method on Orthophosphate Removal from Waste Water. Journal of Applied Phycology, 24, 649-655. https://doi.org/10.1007/s10811-011-9682-3

[14] Caporgno, M.P., Taleb, A., Olkiewicz, M., Font, J., Pruvost, J., Legrand, J. and Bengoa, C. (2015) Microalgae Cultivation in Urban Waste Water: Nutrient Removal and Biomass Production for Biodiesel and Methane. Algal Research, 10, 232-239. https://doi.org/10.1016/j.algal.2015.05.011

[15] Abou-Shanab, R.A.I., Ji, M.K., Kim, H.C., Paeng, K.J. and Jeon, B.H. (2013) Microalgal Species Growing on Piggery Wastewater as a Valuable Candidate for Nutrient Removal and Biodiesel Production. Journal of Environmental Management, 115, 257-264. https://doi.org/10.1016/j.jenvman.2012.11.022

[16] Sun, X., Wang, C., Li, Z., Wang, W., Tong, Y. and Wei, J. (2013) Microalgal Cultivation in Wastewater from the Fermentation Effluent in Riboflavin $\left(B_{2}\right)$ Manufacturing for Biodiesel Production. Bioresource Technology, 143, 499-504.

https://doi.org/10.1016/j.biortech.2013.06.044 
[17] Luo, L., He, H., Yan, C., Wen, S., Zeng, G., Wu, M., Zhou, Z. and Lou, W. (2016) Nutrient Removal and Lipid Production by Coelastrella sp. in Anaerobically and Aerobically Treated Swine Wastewater. Bioresource Technology, 216, 135-141. https://doi.org/10.1016/j.biortech.2016.05.059

[18] Cheng, J., Ye, Q., Xu, J., Yang, Z., Zhou, J. and Chen, K. (2016) Improving Pollutants Removal by Microalgae Chlorella PY-ZU1 with $15 \% \mathrm{CO}_{2}$ from Undiluted Anaerobic Digestion Effluent of Food Wastes with Ozonation Pretreatment. Bioresource Technology, 216, 273-279. https://doi.org/10.1016/j.biortech.2016.05.069

[19] Aslan, S. and Kapdan, I.K. (2006) Batch Kinetics of Nitrogen and Phosphorous Removal from Synthetic Wastewater by Algae. Ecological Engineering, 28, 64-70. https://doi.org/10.1016/j.ecoleng.2006.04.003

[20] APHA (2005) Standard Methods for the Examination of Water and Waste Water. 21st Edition, American Public Health Association, Washington DC.

[21] Anderson, R.A. (2005) Algal Culturing Techniques. Elsevier Inc., Amsterdam.

[22] Stanier, R.Y., Kunisawa, R., Mandel, M. and Cohen-Bazire, G. (1971) Purification and Properties of Unicellular Blue-Green Algae (Order Chroococcales). Bacteriological Reviews, 35, 171-205.

[23] Guillard, R.R.L. and Ryther, J.H. (1962) Studies on Marine Planktonic Diatoms I. Cyclotella nana Hustedt and Detonula confervacea (Cleve) Gran. Canadian Journal of Microbiology, 8, 229-239. https://doi.org/10.1139/m62-029

[24] Wellburn, A.R. (1994) The Spectral Determination of Chlorophyll a and b, as Well as Total Carotenoids, Using Various Solvents with Spectrophotometers of Different Resolution. Journal of Plant Physiology, 144, 307-313. https://doi.org/10.1016/S0176-1617(11)81192-2

[25] Kirk, J.T.O. (1967) Studies on the Dependence of Chlorophyll Synthesis on Protein Synthesis in Euglena gracilis, Together with a Nomogram for Determination of Chlorophyll Concentration. Planta, 78, 200-207. https://doi.org/10.1007/BF00406651

[26] Lowry, O.H., Rosebrough, N.J., Farr, A.L. and Randall, RJ. (1951) Protein Measurement with the Folin Phenol Reagent. The Journal of Biological Chemistry, 193, 265-275.

[27] Gerhardt, P., Murray, R.G.E., Wood, W.A. and Krieg, N.R. (1994) Methods for General and Molecular Bacteriology. ASM, Washington DC.

[28] Leyva, A., Quintana, A., Sanchez, M., Rodriguez, E.N., Cremata, J. and Sanchez, J.C. (2008) Rapid and Sensitive Anthrone-Sulfuric Acid Assay in Microplate Format to Quantify Carbohydrate in Biopharmaceutical Products: Method Development and Validation. Biologicals, 36, 134-141. https://doi.org/10.1016/j.biologicals.2007.09.001

[29] Folch, J., Lees, M. and Stanley, G.H.S. (1956) A Simple Method for the Isolation and Purification of Total Lipids from Animal Tissues. The Journal of Biological Chemistry, 226, 497-509.

[30] Li, X., Hu, H.Y., Gan, K. and Yang, J. (2010) Growth and Nutrient Removal Properties of a Fresh Water Microalga Scenedesmus sp. LX1 under Different Kinds of Nitrogen Sources. Ecological Engineering, 36, 379-381. https://doi.org/10.1016/j.ecoleng.2009.11.003

[31] Cho, S., Lee, N., Park, S., Yu, J., Luong, T.T., Oh, Y.K. and Lee, T. (2013) Microalgae Cultivation for Bioenergy Production Using Wastewaters from a Municipal WWTP as Nutritional Sources. Bioresource Technology, 131, 515-520.

https://doi.org/10.1016/j.biortech.2012.12.176 
[32] Cabanelas, I.T.D., Ruiz, J., Arbib, Z., Chinalia, F.A., Garrido-Perez, C., Rogalla, F, Nascimento, I.A. and Perales, J.A. (2013) Comparing the Use of Different Domestic Wastewaters for Coupling Microalgal Production and Nutrient Removal. Bioresource Technology, 131, 429-436. https://doi.org/10.1016/j.biortech.2012.12.152

[33] Li, Y., Zhou, W., Hu, B., Min, M., Chen, P. and Ruan, R.R. (2011) Integration of Algae Cultivation as Biodiesel Production Feedstock with Municipal Wastewater Treatment: Strains Screening and Significance Evaluation of Environmental Factors. Bioresource Technology, 102, 10861-10867.

https://doi.org/10.1016/j.biortech.2011.09.064

[34] Lizzul, A.M., Hellier, P., Purton, S., Baganz, F., Ladommatos, N. and Campos, L. (2014) Combined Remediation and Lipid Production Using Chlorella sorokiniana Grown on Wastewater and Exhaust Gases. Bioresource Technology, 151, 12-18. https://doi.org/10.1016/j.biortech.2013.10.040

[35] Gupta, P.L., Choi, H.J. and Lee, S.M. (2016) Enhanced Nutrient Removal from Municipal Wastewater Assisted by Mixotrophic Microalgal Cultivation Using Glycerol. Environmental Science and Pollution Research, 23, 10114-10123. https://doi.org/10.1007/s11356-016-6224-1

[36] Feng, Y., Li, C. and Zhang, D. (2011) Lipid Production of Chlorella vulgaris Cultured in Artificial Wastewater Medium. Bioresource Technology, 102, 101-105. https://doi.org/10.1016/j.biortech.2010.06.016

[37] Ji., F., Liu, Y., Hao, R., Li, G., Zhou, Y. and Dong, R. (2014) Biomass Production and Nutrients Removal by a New Microalgae Strain Desmodesmus sp. in Anaerobic Digestion Wastewater. Bioresource Technology, 161, 200-207. https://doi.org/10.1016/j.biortech.2014.03.034

[38] Yang, X., Wu, X., Hao, H. and He, Z. (2008) Mechanisms and Assessment of Water Eutrophication. Journal of Zhejiang University SCIENCE B, 9, 197-209. https://doi.org/10.1631/jzus.B0710626

[39] Ruiz, J., Alvarez, P., Arbib, Z., Garrido, C., Barragan, J. and Perales, J.A. (2011) Effect of Nitrogen and Phosphorus Concentration on Their Removal Kinetic in Treated Urban Wastewater by Chlorella vulgaris. International Journal of Phytoremediation, 13, 884-896. https://doi.org/10.1080/15226514.2011.573823

[40] Kim, J., Liu, Z., Lee, J.Y. and Lu, T. (2013) Removal of Nitrogen and Phosphorus from Municipal Wastewater Effluent Using Chlorella vulgaris and Its Growth Kinetics. Desalination and Water Treatment, 51, 7800-7806.

https://doi.org/10.1080/19443994.2013.779938

[41] Shaker, S., Nemati, A., Montazeri-Najafabady, N., Mobasher, M.A., Morowvat, M.H. and Ghasemi, Y. (2015) Treating Urban Wastewater: Nutrient Removal by Using Immobilized Green Algae in Batch Cultures. International Journal of Phytoremediation, 17, 1177-1182. https://doi.org/10.1080/15226514.2015.1045130

[42] Canedo-Lopez, Y., Ruiz-Martin, A. and Zaval-Loria, J.C. (2016) A Two-Stage Culture Process Using Chlorella vulgaris for Urban Wastewater Nutrient Removal and Enhanced Algal Lipid Accumulation under Photoautotrophic and Mixotrophic Conditions. Journal of Renewable and Sustainable Energy, 8, Article ID: 033102. https://doi.org/10.1063/1.4954078

[43] Goldberg, I.K. and Cohen, Z. (2006) The Effect of Phosphate Starvation on the Lipid and Fatty Acid Composition of the Fresh Water Eustigmatophyte Monodus subterraneus. Phytochemistry, 67, 696-701. https://doi.org/10.1016/j.phytochem.2006.01.010

[44] Rasoul-Amini, S., Montazeri-Najafabady, N., Shaker, S., Safari, A., Kazemi, A., Mousavi, P., et al. (2014) Removal of Nitrogen and Phosphorus from Wastewater 
Using Microalgae Free Cells in Batch Culture System. Biocatalysis and Agricultural Biotechnology, 3, 126-131. https://doi.org/10.1016/j.bcab.2013.09.003

[45] Hongyang, S., Yalei, Z., Chunmin, Z., Xuefei, Z. and Jinpeng, L. (2011) Cultivation of Chlorella pyrenoidosa in Soybean Processing Wastewater. Bioresource Technology, 102, 9884-9890. https://doi.org/10.1016/j.biortech.2011.08.016

[46] Ji, M., Abou-Shanab, R.A.I., Kim, S., Salama, E., Lee, S., Kabra, A.N., Lee, Y., Hong, S. and Jeon, B. (2013) Cultivation of Microalgae Species in Tertiary Municipal Wastewater Supplemented with $\mathrm{CO}_{2}$ for Nutrient Removal and Biomass Production. Ecological Engineering, 58, 142-148.

https://doi.org/10.1016/j.ecoleng.2013.06.020

[47] Min, M., Wang, L., Li, Y., Mohr, M.J., Hu, B., Zhou, W., Chen, P. and Ruan, R. (2011) Cultivating Chlorella sp. in a Pilot-Scale Photobioreactor Using Centrate Wastewater for Microalgae Biomass Production and Wastewater Nutrient Removal. Applied Biochemistry and Biotechnology, 165, 123-137. https://doi.org/10.1007/s12010-011-9238-7

[48] Cho, S., Luong, T.T., Lee, D., Oh, Y. and Lee, T. (2011) Reuse of Effluent Water from a Municipal Wastewater Treatment Plant in Microalgae Cultivation for Biofuel Production. Bioresource Technology, 102, 8639-8645.

https://doi.org/10.1016/j.biortech.2011.03.037

[49] Dahmani, S., Zerrouki, D., Ramanna, L., Rawat, I. and Bux, F. (2016) Cultivation of Chlorella pyrenoidosa in Outdoor Open Raceway Pond Using Domestic Wastewater as Medium in Arid Desert Region. Bioresource Technology, 219, 749-752. https://doi.org/10.1016/j.biortech.2016.08.019

[50] Wang, L., Min, M., Li, Y., Chen, P., Chen, Y., Liu, Y., Wang, Y. and Ruan, R. (2010) Cultivation of Green Algae Chlorella sp. in Different Wastewaters from Municipal Wastewater Treatment Plant. Applied Biochemistry and Biotechnology, 162, 11741186. https://doi.org/10.1007/s12010-009-8866-7

[51] Li, Y., Chen, Y., Chen, P., Min, M., Zhou, W., Martinez, B., Zhu, J. and Ruan, R. (2011) Characterization of a Microalga Chlorella sp. Well Adapted to Highly Concentrated Municipal Wastewater for Nutrient Removal and Biodiesel Production. Bioresource Technology, 102, 5138-5144.

https://doi.org/10.1016/j.biortech.2011.01.091

Scientific Research Publishing

\section{Submit or recommend next manuscript to SCIRP and we will provide best} service for you:

Accepting pre-submission inquiries through Email, Facebook, LinkedIn, Twitter, etc. A wide selection of journals (inclusive of 9 subjects, more than 200 journals)

Providing 24-hour high-quality service

User-friendly online submission system

Fair and swift peer-review system

Efficient typesetting and proofreading procedure

Display of the result of downloads and visits, as well as the number of cited articles

Maximum dissemination of your research work

Submit your manuscript at: http://papersubmission.scirp.org/

Or contact jep@scirp.org 